\title{
UPTAKE AND METABOLISM OF PYRUVATE AND LACTATE DURING PREIMPLANTATION DEVELOPMENT OF THE MOUSE EMBRYO IN VITRO
}

\author{
P. QUINN* AND R. G. WALES \\ Department of Veterinary Physiology, University of Sydney, N.S.W. 2006, Australia
}

\section{(Received 10th October 1972)}

Summary. The incorporation of substrate carbon from pyruvate and lactate has been measured at all stages of preimplantation development in the mouse embryo using substrates labelled at the $\mathrm{C} 2$ position. Embryos were cultured for $24 \mathrm{hr}$ in medium containing pyruvate $(0.5$ $\mathrm{mM}$ ) or lactate $(5 \mathrm{~mm})$, alone or in combination and the accumulation of label in various intracellular fractions was measured.

The incorporation of both pyruvate and lactate carbon increased with increasing development of the embryos. Before the morula stage, the presence of unlabelled lactate in the medium depressed the incorporation of C2 of pyruvate whereas the opposite effect occurred when embryos were cultured in $\left[2-{ }^{14} \mathrm{C}\right]$ lactate in the presence of unlabelled pyruvate. The combined incorporation of carbon from both pyruvate and lactate was greater than that from either substrate alone at all stages of development. Lactate contributed a greater proportion to the combined incorporation of substrate carbon than pyruvate at all stages of development. The increased incorporation of substrate carbon into cultured two-cell embryos in the combination of pyruvate and lactate was almost entirely due to the stimulated accumulation of carbon in the protein fraction of the embryos. Incorporation into this fraction contributed proportionately less to the increased total incorporation into the embryos at the later stage of development.

Alanine, glutamic acid and aspartic acid accounted for most of the carbon incorporated into the basic compounds of the acid-soluble fraction of the embryos. Labelled malate and citrate were found in the acidic compounds of this fraction when two-cell embryos were cultured in $\left[2-{ }^{14} \mathrm{C}\right]$ pyruvate. After the eight-cell stage, labelled lactate, as well as malate and citrate, accumulated in embryos cultured in medium containing pyruvate, lactate or their combination. Labelled pyruvate only accumulated in these embryos during culture in media containing $\left[2-{ }^{14} \mathrm{C}\right]$ pyruvate alone or $\left[2-{ }^{14} \mathrm{C}\right]$ lactate and unlabelled pyruvate.

\section{INTRODUCTION}

Lactate, in contrast to pyruvate, cannot sustain the development of the mouse

* Present address: The Jackson Laboratory, Bar Harbor, Maine 04609, U.S.A. 
oocyte and fertilized ovum in vitro (Biggers, Whittingham \& Donahue, 1967). Even at the two-cell stage, fewer embryos develop into blastocysts when cultured in medium containing lactate as compared to pyruvate, except when very high concentrations of lactate are used (Brinster, 1965a, b; Wales \& Whittingham, 1973). In a suitable combination of pyruvate and lactate, however, more two-cell mouse embryos develop to the blastocyst stage in vitro than in the presence of either substrate alone (Brinster, 1965b; Wales \& Whittingham, 1973).

Wales \& Whittingham (1967) suggested that the more efficient utilization of pyruvate than lactate by one- and two-cell mouse embryos might be responsible for the ability of pyruvate to sustain development of the early mouse embryo. Although oxidation, rather than incorporation, accounts for most of the pyruvate carbon used by the preimplantation mouse embryo (Brinster, 1969), pyruvate carbon incorporated into the embryo is widely distributed throughout the metabolic pools of the embryo (Wales \& Whittingham, 1970, 1973; Murdoch \& Wales, 1971) and this incorporation probably plays an important part in overall development. The combination of pyruvate and lactate in the culture medium not only supports the development of more two-cell mouse embryos to the blastocyst stage than either substrate alone (Brinster, 1965b), but also increases the incorporation of substrate carbon into the two-cell embryo (Wales \& Whittingham, 1973).

The present experiments were aimed at assessing the rôle of pyruvate and lactate in the metabolism of the mouse embryo throughout preimplantation development.

\section{MATERIALS AND METHODS}

\section{General}

Essentially the same methods were used for the culture, collection and extraction of embryos and the fractionation of their metabolites as those described previously (Wales \& Whittingham, 1970).

Mouse embryos were collected by flushing the reproductive tracts of superovulated random-bred albino mice at specific times after mating (Brinster, 1965c). The basic medium was modified Krebs-Ringer bicarbonate solution containing $25 \mathrm{~mm}$-DL-sodium lactate, $0.25 \mathrm{~mm}$-sodium pyruvate, $1 \mathrm{mg}$ bovine serum albumin $/ \mathrm{ml}, 60 \mu \mathrm{g}$ penicillin $/ \mathrm{ml}$, and $50 \mu \mathrm{g}$ streptomycin $/ \mathrm{ml}$ (Brinster, $1965 \mathrm{~b})$. The embryos were washed twice $(2 \mathrm{ml} /$ wash) in substrate-free medium before incubation in medium containing radioactively labelled substrates. Before use, radioactive substrates were stored as small dried aliquots at $-40^{\circ} \mathrm{C}$ to minimize decomposition (Wales \& Whittingham, 1971).

\section{Culture and recovery of embryos}

Embryos were cultured for $24 \mathrm{hr}$ at $37^{\circ} \mathrm{C}$ in $20-\mu \mathrm{l}$ droplets of medium (twenty embryos/drop) under oil using $5 \% \mathrm{CO}_{2}: 95 \%$ air (v/v) as the gas phase (Brinster, 1963). Between 60 and 120 embryos from the one-cell to morula stage were cultured in medium containing $0.5 \mathrm{~mm}-\left[2-{ }^{14} \mathrm{C}\right]$ sodium pyruvate $(5.3 \mu \mathrm{Ci} / \mu \mathrm{mol})$ with and without the addition of non-radioactive 
5 mm-DL-sodium lactate. Between 100 and 260 embryos from the two-cell to morula stage were cultured in $5 \mathrm{~mm}-\left[2-{ }^{14} \mathrm{C}\right] \mathrm{DL}$-sodium lactate $(1.43 \mu \mathrm{Ci} / \mu \mathrm{mol})$ with and without the addition of non-radioactive $0.5 \mathrm{~mm}$-sodium pyruvate. In view of the report of Donahue \& Stern (1968) on the solubility of pyruvate in the oil used to cover the drops of culture medium, nine 20- $\mu$ drops of medium containing $\left[2-{ }^{14} \mathrm{C}\right]$ pyruvate $(0.5 \mathrm{~mm}, 6.8 \mu \mathrm{Ci} / \mu \mathrm{mol})$ and no embryos were incubated under oil for $24 \mathrm{hr}$ at $37^{\circ} \mathrm{C}$. At the end of this period, less than $0.015 \%$ of the total radioactivity in the culture dish was found in the oil and there was no significant difference in the amount of radioactivity in the medium before and after incubation.

At the completion of culture, ten embryos, which had undergone normal development or, in the case of two-cell embryos incubated in $\left[2-{ }^{14} \mathrm{C}\right]$ lactate, had remained unchanged, were removed from the medium and collected by centrifugation. Before the blastocyst stage, the embryos were centrifuged through isotonic sucrose containing the appropriate unlabelled substrate (Wales \& Biggers, 1968). Blastocysts were collected by centrifugation through non-radioactive culture medium (Wales \& Whittingham, 1970). The total uptake of radioactive substrate in these embryos was then assessed by liquid scintillation counting. The remaining embryos which had developed during culture were collected in a similar manner, recovered from the broken tip of the centrifuge tube in a small volume of fluid and stored at $-20^{\circ} \mathrm{C}$ until metabolic products were extracted and assayed.

\section{Extraction and identification of metabolites}

After thawing and the addition of $5 \mathrm{mg}$ bovine serum albumin to act as carrier for labelled compounds, the embryos were fractionated into acid-soluble, protein and lipid portions as described by Wales \& Whittingham (1970). Compounds in the acid-soluble fraction were separated into acidic, basic and neutral portions using columns of ion-exchange resin (Wales \& Whittingham, 1970). Quantitative recovery of radioactivity applied to the columns was achieved $(97 \pm 3 \%)$.

Only small amounts of radioactivity were available for further identification of compounds in the acid-soluble fraction of the embryos and thus samples from eight-cell embryos and morulae which had been incubated in similar media were pooled. Considerably less material was available in extracts of cultured two-cell embryos and samples of embryos which had been incubated in either radioactive pyruvate or lactate were pooled. Basic and acidic compounds in these combined samples were separated by ion-exchange chromatography as before and the eluates containing these fractions reduced in volume under a stream of air. The basic compounds were differentiated by paper chromatography as described previously (Quinn \& Wales, 1971). Acidic compounds in the acid-soluble fraction were chromatographed on a column of silicic acid using hexane-butanol mixtures as the solvent (O'Shea \& Wales, 1968). The identity of the acidic compounds was further checked by paper chromatography with $n$-butanol:acetic acid: water $(4: 1: 5 \mathrm{v} / \mathrm{v})$ as the solvent.

Radioactivity in all samples was assayed by liquid scintillation techniques using $5 \mathrm{ml}$ Triton X100-toluene $(1: 2 \mathrm{v} / \mathrm{v})$ containing $0 \cdot 4 \%$ (w/v) 2,5-diphenyl- 
oxazole and $0.01 \%(\mathrm{w} / \mathrm{v}) 1,4$ bis (4-methyl-5-phenyloxazol-2-yl) benzene for each $0.4 \mathrm{ml}$ of aqueous sample.

\section{Statistical analysis}

All data were transformed to logarithms before analysis to minimize the effects of heterogeneous variance. The design of the experiments to study the metabolism of pyruvate was factorial and the results were assessed by standard analysis of variance. Because radioactive lactate would not support development of embryos at the two-cell stage, results of the experiments involving this substrate were analysed by the method of unweighted means for disproportionate sub-class numbers (Snedecor, 1957).

\section{Development of embryos}

\section{RESULTS}

Table 1 shows the development of embryos during 24-hr periods of culture. Fewer embryos developed at the one- and two-celi stages than at the eight-cell or morula stage. Since only pyruvate will support development of one-cell mouse embryos (Biggers et al., 1967), no embryos were cultured in radioactive lactate at this stage. Even at the two-cell stage, $\left[2-{ }^{14} \mathrm{C}\right]$ lactate, when present

Table 1. Development of mouse embryos cultured for $24 \mathrm{hr}$ in media containing $0.5 \mathrm{~mm}-\left[2-{ }^{14} \mathrm{C}\right]$ pyruvate or $5 \mathrm{~mm}-\left[2-{ }^{14} \mathrm{C}\right] \mathrm{DL}$-sodium lactate

\begin{tabular}{c|c|c|c|l}
\hline $\begin{array}{c}\text { Stage at } \\
\text { start of } \\
\text { culture }\end{array}$ & $\begin{array}{c}\text { Substrates } \\
\text { in } \\
\text { medium* }\end{array}$ & $\begin{array}{c}\text { No. } \\
\text { of } \\
\text { replicates }\end{array}$ & $\begin{array}{c}\text { Mean no. } \\
\text { of embryos } \\
\text { per replicate }\end{array}$ & $\begin{array}{c}\text { Stage of development } \\
\text { reached after 24 hr culture } \\
\text { (\% of embryos cultured })\end{array}$ \\
\hline 1-cell & $\mathrm{P}$ & 2 & 105 & 2-cell $(44 \%)$ \\
& $\mathrm{P}+\mathrm{L}$ & 2 & 110 & 2-cell $(51 \%)$ \\
2-cell & $\mathrm{P}$ & 2 & 110 & $4-, 8$-cell $(82 \%)$ \\
& $\mathrm{P}+\mathrm{L}$ & 2 & 110 & $4-, 8$-cell $(86 \%)$ \\
& $\mathrm{L}$ & 3 & 130 & $4-, 8$-cell $(0 \%) ; 2$-cell $(56 \%) \dagger$ \\
& $\mathrm{L}+\mathrm{P}$ & 2 & 134 & $4-, 8$-cell $(69 \%) ; 2$-cell $(30 \%) \dagger$ \\
8 -cell & $\mathrm{P}$ & 2 & 100 & Morula $(94 \%)$ \\
& $\mathrm{P}+\mathrm{L}$ & 2 & 100 & Morula $(97 \%)$ \\
& $\mathrm{L}$ & 3 & 190 & Morula $(89 \%)$ \\
& $\mathrm{L}+\mathrm{P}$ & 3 & 190 & Morula $(80 \%)$ \\
Morula & $\mathrm{P}$ & 2 & 80 & Blastocyst $(98 \%)$ \\
& $\mathrm{P}+\mathrm{L}$ & 2 & 80 & Blastocyst $(90 \%)$ \\
& $\mathrm{L}$ & 2 & 190 & Blastocyst $(94 \%)$ \\
& $\mathrm{L}+\mathrm{P}$ & 2 & 190 & Blastocyst $(87 \%)$ \\
\hline
\end{tabular}

* $\mathrm{P}=\left[2-{ }^{14} \mathrm{C}\right]$ pyruvate; $\mathrm{P}+\mathrm{L}=\left[2-{ }^{14} \mathrm{C}\right]$ pyruvate $+5 \mathrm{~mm}$-unlabelled lactate; $\mathrm{L}=\left[2-1^{14} \mathrm{C}\right]$ lactate $; \mathrm{L}+\mathrm{P}=\left[2-{ }^{14} \mathrm{C}\right] \mathrm{lactate}+0.5 \mathrm{~mm}$-unlabelled pyruvate.

+ With incubations in $\left[2-{ }^{14} \mathrm{C}\right]$ lactate, undivided two-cell embryos were collected for fractionation of metabolites.

as the sole energy substrate, did not support development of embryos to the four- to eight-cell stage. This labelled substrate could support development when present as the only substrate from the eight-cell stage onwards. When lactate and pyruvate were combined in the medium, however, a substantial proportion of one- and two-cell embryos developed during the 24-hr culture period.

Incorporation of $\left[2-{ }^{14} C\right]$ pyruvate

Data for the accumulation of carbon-2 (C2) of pyruvate in embryos and its 


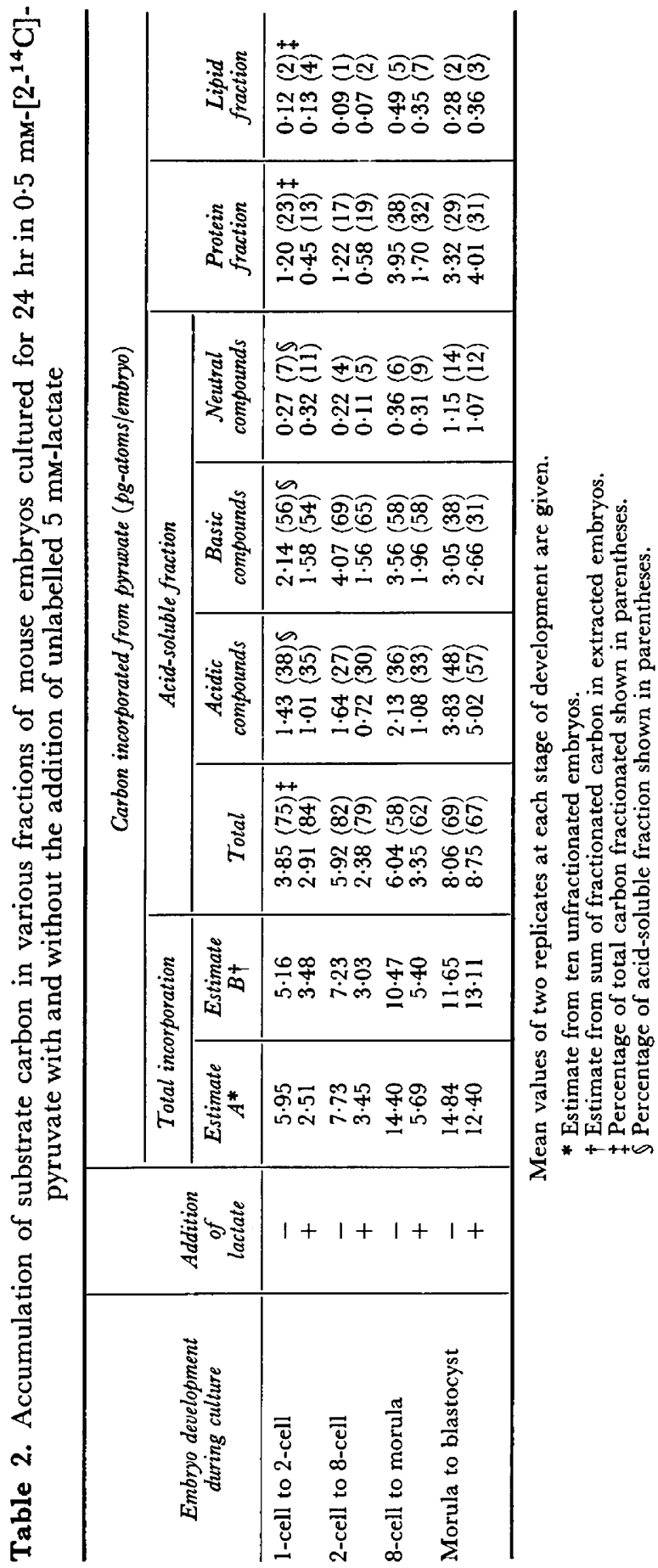




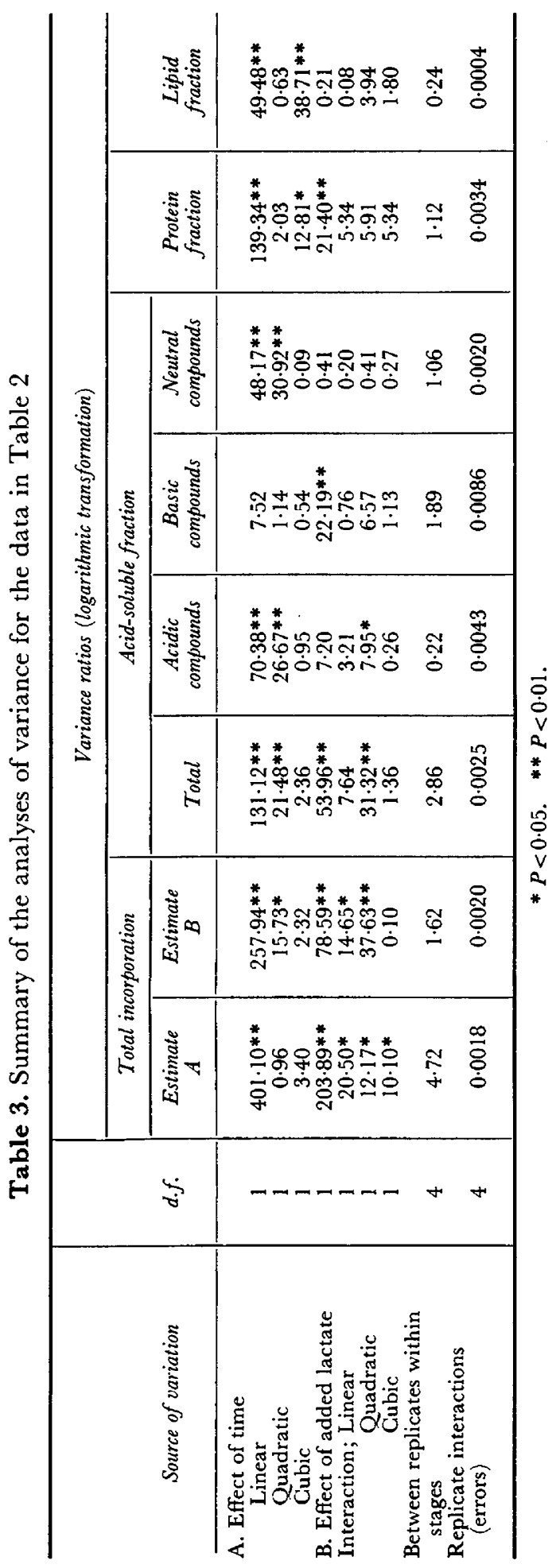


distribution in various fractions of the embryos are given in Table 2 with a summary of the analyses of variance in Table 3 . The sum of the substrate carbon accumulated in the various fractions of the embryos (Estimate B, Table 2) was in good agreement $(97 \pm 7 \%)$ with the estimate of total carbon incorporated based on a sample of ten embryos (Estimate A). The incorporation of $\mathrm{C} 2$ of pyruvate into nearly all fractions of the embryos increased as development of the embryos progressed, both in the presence and in the absence of added lactate. During the first 3 days of embryonic development, the addition of unlabelled lactate to the culture medium depressed the incorporation of $\mathrm{C} 2$ of pyruvate into the embryos. From the morula stage, there was little difference in the uptake of $\mathrm{C} 2$ of pyruvate whether or not unlabelled lactate was included in the culture medium.

The acid-soluble fraction accounted for 60 to $85 \%$ of the total amount of C2 of pyruvate accumulated in the embryos. Before the morula stage, over half of the $\mathrm{C} 2$ of pyruvate accumulating in the acid-soluble fraction was found in basic compounds and approximately one third in acidic compounds. In cultured morulae, the distribution of acid-soluble carbon between these two groups of compounds was reversed. At all stages of development, only 5 to $15 \%$ of the C2 of pyruvate accumulating in the acid-soluble fraction of the embryos was found in the neutral compounds.

The accumulation of C2 of pyruvate in the protein fraction of the embryos was similar during the first 2 days of development, increased approximately three- to fourfold at the eight-cell stage and remained elevated in blastocysts cultured from the morula stage. Similar trends were evident with the incorporation of $\mathrm{C} 2$ of pyruvate into the lipid fraction of these embryos. The inclusion of unlabelled lactate in the culture medium depressed the incorporation of pyruvate carbon into the protein fraction of the embryos by approximately 50 to $60 \%$ during the first 3 days of development. There was no effect of lactate on the incorporation of pyruvate into the lipid fraction of the embryos.

\section{Incorporation of $\left[2-{ }^{14} \mathrm{C}\right]$ lactate}

The accumulation and distribution of $\mathrm{C} 2$ of lactate in embryos cultured in the presence or absence of unlabelled pyruvate is shown in Table 4 with a summary of the analyses of variance for the data in Table 5. Two-cell embryos which survived but did not develop during the culture period were also collected separately from developing embryos and fractionated. The estimate of total incorporation of $\mathrm{C} 2$ of lactate into embryos based on the summation of carbon in the various fractions of the embryos (Estimate B, Table 4) was slightly higher $(117 \pm 15 \%)$ than the estimate using a sample of ten unfractionated embryos (Estimate A).

The incorporation of $\mathrm{C} 2$ of lactate into most fractions of the embryos increased with increasing development, especially after the morula stage. At the two-cell stage, the addition of unlabelled pyruvate to the culture medium significantly increased the incorporation of $\mathrm{C} 2$ of lactate into most fractions of the embryos but from the eight-cell stage onwards, no such effect was evident (Table 5). 


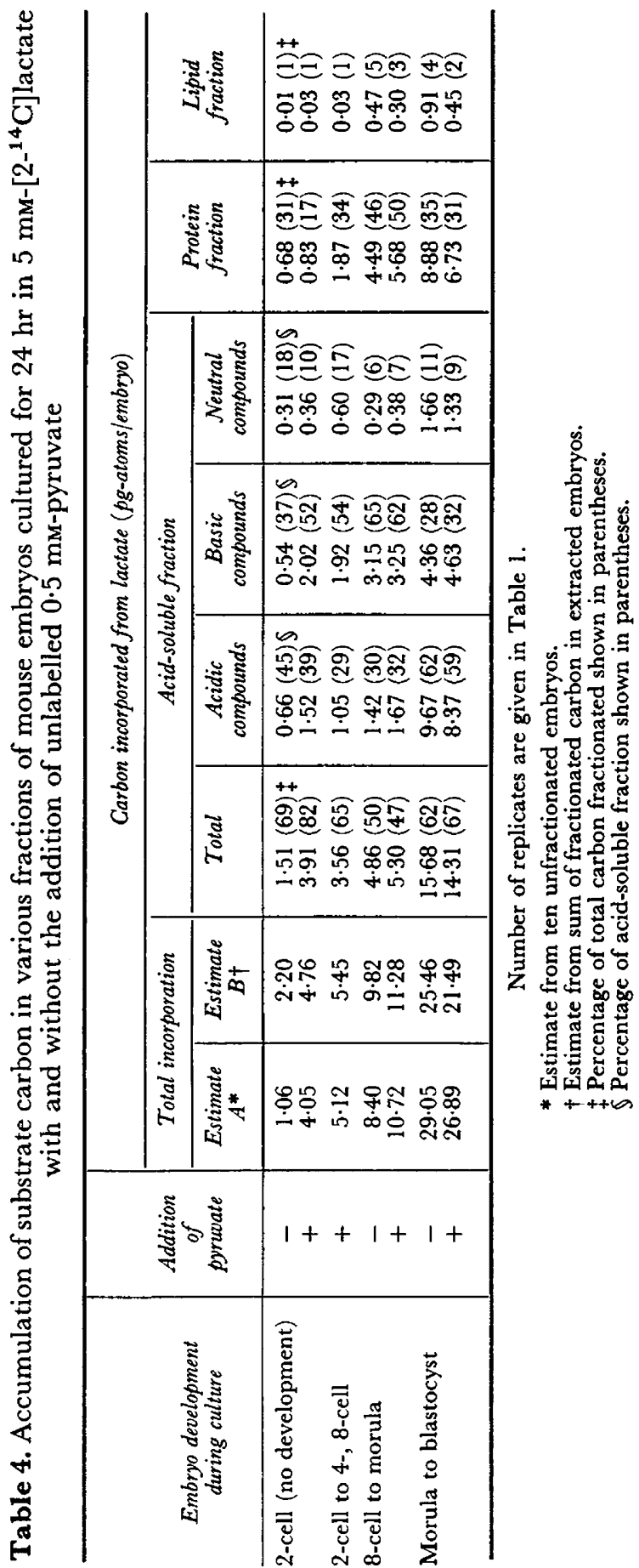




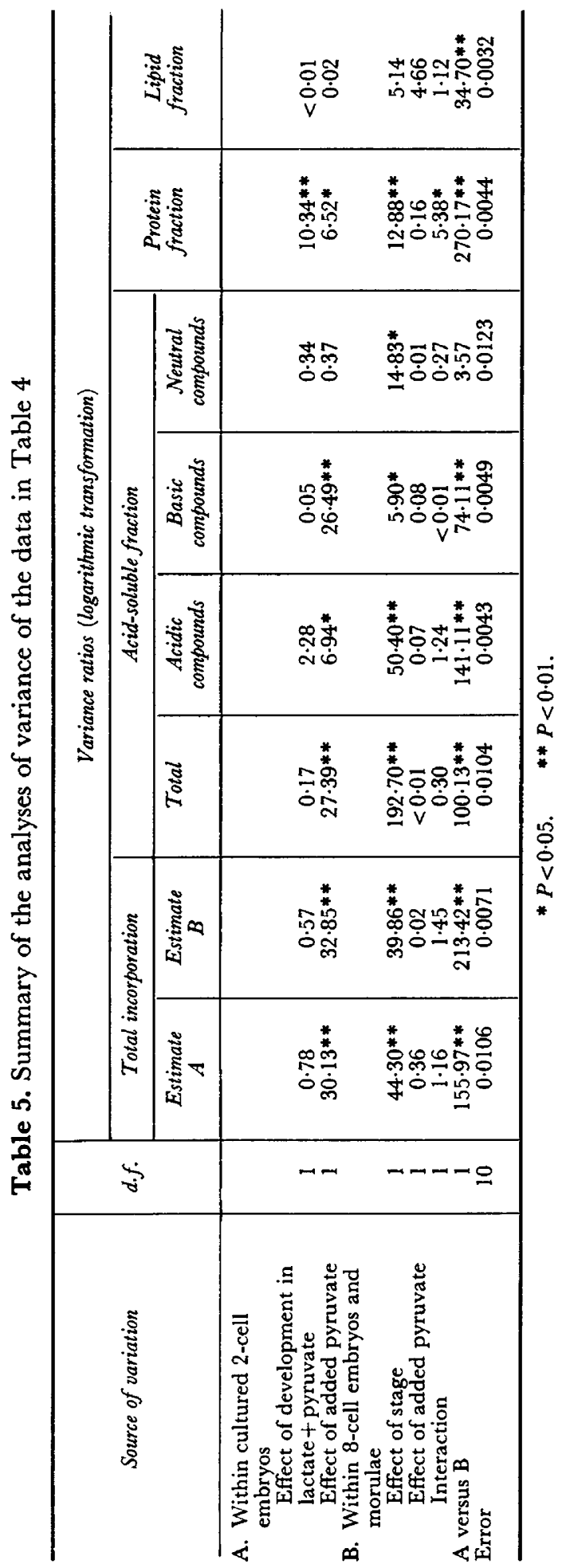


With two-cell embryos cultured in medium containing lactate and pyruvate, it was found that the amount of $\mathrm{C} 2$ of lactate incorporated into the protein fraction of the developing embryos was approximately twice that in the embryos which survived but did not divide. In most other fractions of the embryos, there was very little difference in the incorporation of lactate carbon between developing and non-developing embryos.

In general, the distribution of substrate carbon between the acid-soluble, protein and lipid fractions and between the acidic, basic and neutral compounds of the acid-soluble fraction of the embryos was the same as that in the embryos cultured in $\left[2-{ }^{14} \mathrm{C}\right]$ pyruvate. The proportion of $\mathrm{C} 2$ of lactate in the acidic compounds of the acid-soluble fraction increased with increasing embryonic development whereas a decreasing proportion accumulated in the basic compounds. The incorporation into the neutral compounds comprised 7 to $18 \%$ of the acid-soluble carbon but was more variable than the incorporation of C2 of lactate into the other portions of the acid-soluble fraction.

\section{Relative contributions of pyruvate and lactate to total substrate incorporation}

The effect of the combination of pyruvate and lactate on the total incorporation of exogenous energy substrate was assessed by combining the data of Tables 2 and 4. Substrate accumulation in the embryos resulting from the combination of pyruvate and lactate is shown in Table 6 .

In general, the combination of pyruvate and lactate stimulated the incorporation of substrate carbon into the various fractions of the embryos and this effect became more marked as development progressed. In cultured eight-cell embryos, the accumulation of $\mathrm{C} 2$ of pyruvate alone (Table 2) into most fractions of the embryos was usually greater than that of C2 of lactate alone (Table 4) but in the combination of substrates (Table 6), less than half of the substrate carbon accumulating originated from $\mathrm{C} 2$ of pyruvate. In cultured morulae, the incorporation of $\mathrm{C} 2$ of lactate into most fractions of the embryo was approximately twice that of pyruvate both in the combination of substrates and when each substrate was present in the medium alone.

In developing two-cell embryos, the accumulation of substrate carbon into most fractions of the embryos when pyruvate alone was present in the medium nearly equalled the combined incorporation of carbon from both pyruvate and lactate. In the case of the protein fraction, however, nearly twice as much carbon was incorporated when the combination of substrates was used. This effect was almost entirely responsible for the increased total accumulation of substrate carbon into the embryos from the combination of pyruvate and lactate as compared to that from pyruvate alone. At later stages of development, the incorporation of carbon into the protein fraction was also greater in the combination of substrates. At these later stages, however, the difference in the total incorporation of substrate carbon in the combination of pyruvate and lactate, as compared to each alone, was affected more by the accunulation of C2 into the acid-soluble fraction of the embryos than by accumulation into protein. The contribution of the acidic compounds to this increase in the accumulation of substrate carbon in the acid-soluble fraction of the embryos was greater than that of the basic compounds only after the morula stage. 


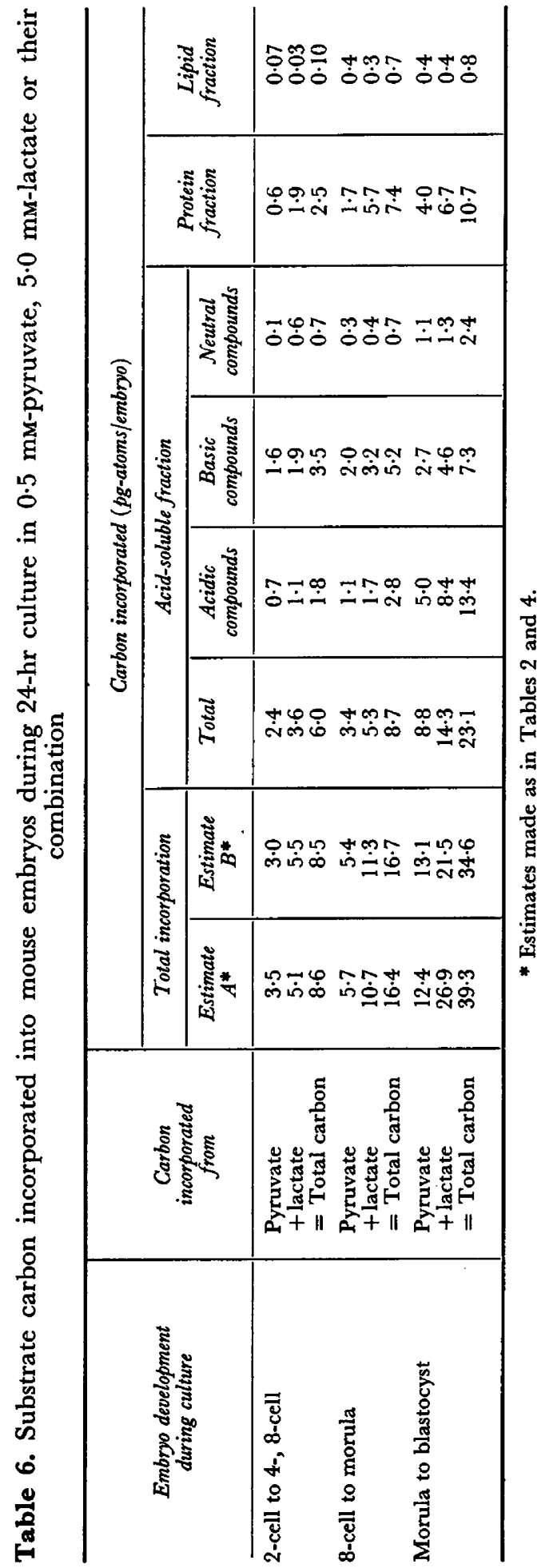




\section{Identification of labelled products}

The proportions of labelled amino acids present in the basic portion of the acid-soluble fraction of embryos cultured in either $2{ }^{14} \mathrm{C}$-labelled pyruvate or lactate are given in Table 7. Recovery of radioactivity applied to the chromatograms varied between 75 and $100 \%$ and of this recovered radioactivity, between 75 and $90 \%$ was present in peaks with $R_{\mathrm{F}}$ values similar to authentic glutamate, aspartate and alanine. Glutamic acid was the major radioactive amino acid present in the embryos with smaller amounts of aspartic acid and alanine. The proportion of radioactivity recovered as alanine decreased at the later stages of embryonic development.

In cultured two-cell embryos, no peaks of radioactivity were detected by silicic acid chromatography of the acidic compounds of the acid-soluble fraction

Table 7. Proportions of labelled amino acids present in the basic compounds of the acid-soluble fraction of mouse embryos cultured in medium containing $2-{ }^{14} \mathrm{C}$-labelled pyruvate or lactate

\begin{tabular}{|c|c|c|c|c|c|}
\hline \multirow{2}{*}{$\begin{array}{l}\text { Embryo development } \\
\text { during culture }\end{array}$} & \multirow{2}{*}{ Substrate* } & \multirow{2}{*}{$\begin{array}{l}\% \text { recovery of } \\
\text { radioactivity applied } \\
\text { to chromatograms }\end{array}$} & \multicolumn{3}{|c|}{$\%$ of recovered radioactivity in: } \\
\hline & & & Aspartate & Glutamate & Alanine \\
\hline 2-cell to 4-cell & $\begin{array}{l}P \text { and } P+L \\
L \text { and } L+P\end{array}$ & $\begin{array}{l}87 \\
85\end{array}$ & $\begin{array}{r}12 \cdot 6 \\
9 \cdot 2\end{array}$ & $\begin{array}{l}52 \cdot 6 \\
32 \cdot 0\end{array}$ & $\begin{array}{l}23 \cdot 0 \\
41 \cdot 1\end{array}$ \\
\hline $\begin{array}{l}\text { 8-cell to morula and } \\
\text { morula to blastocyst }\end{array}$ & $\begin{array}{l}\mathrm{P} \\
\mathrm{P}+\mathrm{L} \\
\mathrm{L} \\
\mathrm{L}+\mathrm{P}\end{array}$ & $\begin{array}{l}76 \\
88 \\
99 \\
81\end{array}$ & $\begin{array}{l}28 \cdot 2 \\
19 \cdot 7 \\
11 \cdot 7 \\
17 \cdot 8\end{array}$ & $\begin{array}{l}47 \cdot 3 \\
42 \cdot 6 \\
69 \cdot 8 \\
47 \cdot 6\end{array}$ & $\begin{array}{r}6 \cdot 6 \\
15 \cdot 5 \\
9 \cdot 1 \\
11 \cdot 0\end{array}$ \\
\hline
\end{tabular}

$* \mathrm{P}=\left[2-{ }^{14} \mathrm{C}\right]$ pyruvate; $\mathrm{P}+\mathrm{L}=\left[2-{ }^{14} \mathrm{C}\right]$ pyruvate +5 mm-unlabelled lactate; $\mathrm{L}=\left[2-{ }^{14} \mathrm{C}\right]$ lactate; $\mathrm{L}+\mathrm{P}=\left[2-{ }^{14} \mathrm{C}\right]$ lactate $+0.5 \mathrm{~mm}$-unlabelled pyruvate.

of embryos cultured in medium containing $\left[2-{ }^{14} \mathrm{C}\right]$ lactate. Two compounds, however, with mobilities similar to malate and citrate and in a ratio of approximately $2: 1$, respectively, were present in this fraction of two-cell embryos cultured in $\left[2-{ }^{14} \mathrm{C}\right]$ pyruvate. After the eight-cell stage, both malate and citrate were detected in the acidic compounds of embryos cultured in either labelled pyruvate or lactate. In all samples of these embryos, the radioactive compound identified as citrate comprised approximately $25 \%$ of the label recovered, whereas the amount of malate accounted for 5 to $20 \%$ of the radioactivity. Labelled lactate was also found in the extracts of these embryos and it accounted for 10 to $40 \%$ of the radioactivity. Pyruvate, however, was only found in extracts of cultured eight-cell embryos and morulae which had been incubated in $\left[2-{ }^{14} \mathrm{C}\right]$ pyruvate in the absence of unlabelled lactate or in medium containing $\left[2-{ }^{14} \mathrm{C}\right]$ lactate and unlabelled pyruvate. In these two cases, the amount of pyruvate present in the embryos represented 25 and $15 \%$, respectively, of the total carbon in the acidic compounds of the acid-soluble fraction. In all samples of embryos after the eight-cell stage, trace amounts of a compound with chromatographic mobility similar to $\alpha$-ketoglutarate were also present.

Insufficient radioactivity accumulated in the neutral compounds of the acid-soluble fraction of the embryos to allow further identification. 


\section{DISCUSSION}

The ability of lactate to support development of two-cell mouse embryos in vitro is less than that of pyruvate (Brinster, 1965a, b) and the present results, together with those of Wales \& Whittingham (1967, 1973), show that the incorporation of substrate carbon from lactate alone, as compared to that from pyruvate, is also lower at this stage. In fact, this difference occurs up to the morula stage but from this stage on, the incorporation of $\mathrm{C} 2$ of lactate is greater than that of pyruvate. After the eight-cell stage, lactate can support development in vitro as effectively as pyruvate and thus it appears that the incorporation of carbon from these substrates is related in part to their ability to support embryonic development.

When one- and two-cell embryos are cultured in media containing lactate as the sole energy source, the production of NADH on the conversion of lactate to pyruvate by lactate dehydrogenase (E.C. 1.1.1.27) (Brinster, 1965c) probably exceeds its utilization since the high ATP to ADP ratio in one- and two-cell mouse embryos (Quinn \& Wales, 1973) would limit the flux of reducing equivalents through the electron transfer chain (Krebs, 1970). This imbalance in the redox potential of the embryos probably inhibits the utilization of sufficient lactate to support development at the early stages of the mouse embryo. This effect would become less at the later stages since the lower ATP to ADP ratio (Quinn \& Wales, 1973) and the functional changes which occur in mitochondria (Calarco \& Brown, 1969; Reinius, 1969) would allow an increased utilization of reducing equivalents. In fact, the greater production of reducing equivalents from the metabolism of lactate compared to that from pyruvate (Schmidt \& Katz, 1969) is probably responsible for the greater incorporation of the $\mathrm{C} 2$ of lactate into the embryo after the morula stage.

The absence of any detectable accumulation of substrate carbon in the form of lactate in two-cell mouse embryos cultured for $24 \mathrm{hr}$ in media containing pyruvate and lactate is in contrast to the situation which occurs after only a 30-min incubation (Wales \& Whittingham, 1973). Diversion of accumulated substrate carbon into the various metabolic pathways of the embryos probably occurs during the longer incubation period so that only products such as malate and citrate accumulate. At the later stages of development, however, pyruvate and lactate, as well as tricarboxylic acid (TCA) cycle intermediates are found within the embryo and this could be due partly to the accumulation of these compounds in the blastocoele fluid as occurs in the rabbit embryo (P. Quinn \& R. G. Wales, unpublished observations). The absence of any accumulation of pyruvate in embryos after culture from the eight-cell and morula stage in certain combinations of pyruvate and lactate could be related to the relative rates of interconversion of pyruvate and lactate and to the rate of entry of pyruvate into the metabolic pathways of the embryo.

The accumulation of C2 from both pyruvate and lactate into the amino acids, glutamate, alanine and aspartate, is similar to that which occurs in twocell mouse embryos during a 30-min incubation (Wales \& Whittingham, 1973) and probably reflects the mode of entry of substrate carbon into the protein fraction of the embryos. The decreased proportion of carbon which accumulated 
in alanine during the later stages of embryonic development indicates that the direct conversion of pyruvate to alanine decreases as the activity of the TCA cycle increases (Quinn \& Wales, 1971).

The significance and identity of the neutral compounds accumulated in the acid-soluble fraction of the embryos remain unknown. It is unlikely, however, that glucose or glycogen accumulate in this fraction of mouse embryos cultured in pyruvate or lactate, since the mouse embryo lacks the enzyme phosphopyruvate carboxylase (E.C. 4.1.1.32) which plays a major rôle in gluconeogenesis from pyruvate (Quinn \& Wales, 1971).

Other studies have shown that the combination of pyruvate and lactate is more beneficial to the growth and metabolism of the two-cell mouse embryo than either substrate alone (Brinster, 1965b; Wales \& Whittingham, 1973). Similarly, in the present experiments, more substrate carbon was incorporated into nearly all fractions of the embryos from the combination of pyruvate and lactate than from either substrate alone at all stages of development. Although exchange between the carbon moiety of pyruvate and lactate can result in no net incorporation of lactate into tissue despite an increased uptake of lactate carbon in the presence of other substrates (Schmidt \& Katz, 1969), the present results amply demonstrate that, in the mouse embryo, the total incorporation of carbon from exogenous energy substrates increases when pyruvate and lactate are both added to the culture medium. This stimulated incorporation of substrate carbon from the combination of both substrates may be caused by the stabilization of the NAD-couple in the embryo at a ratio favourable for development (Brinster, 1965b).

A stimulated incorporation of substrate carbon into the protein fraction of the embryos is the major response to the combination of pyruvate and lactate at the two-cell stage. These results agree with the suggestion of Wales \& Whittingham (1973) that the beneficial effect of the combination of pyruvate and lactate on the development of two-cell mouse embryos could be due in part to a stimulated level of macromolecular synthesis. At the later stages of development, the greater incorporation of substrate carbon into the protein fraction of the embryos is probably due in part to the increased activity of the TCA cycle at this time (Quinn \& Wales, 1971, 1973). The greater turnover of intermediates in the cycle produces a greater supply of reducing equivalents. This would be expected to increase the incorporation of substrate carbon into macromolecules by providing the necessary energy for the anabolic reactions.

\section{ACKNOWLEDGMENTS}

The authors are indebted to Professor C. W. Emmens for interest and criticism. The work was aided by a grant from the Australian Research Grants Committee. One of us (P.Q.) was supported by an Australian Wool Board PostGraduate Studentship.

\section{REFERENGES}

Biggers, J. D., Whittingham, D. G. \& Donahue, R. D. (1967) The pattern of energy metabolism in the mouse oocyte and zygote. Proc. nain. Acad. Sci. U.S.A. 58, 560. 
Brinster, R. L. (1963) A method for in vitro cultivation of mouse ova from two-cell to blastocyst. Expl Cell Res. 32, 205.

BRINSTER, R. L. (1965a) Studies on the development of mouse embryos in vitro. II. The effect of energy source. F. exp. Zool. 158, 59.

BRINSTER, R. L. (1965b) Studies on the development of mouse embryos in vitro. IV. Interaction of energy sources. F. Reprod. Fert. 10, 227.

BRINSTER, R. L. (1965c) Studies on the development of mouse embryos in vitro. I. The effect of osmolarity and hydrogen ion concentration. F. exp. Zool. 158, 49.

Brinster, R. L. (1969) Mammalian embryo culture. In: The Mammalian Oviduct, p. 419. Eds. E. S. E. Hafez and R. J. Blandau. University of Chicago Press, Chicago.

Calarco, P. G. \& Brown, E. H. (1969) An ultrastructural and cytological study of preimplantation development of the mouse. 7. exp. Zool. 171, 253.

Donahue, R. P. \& STERn, S. (1968) Follicular cell support of oocyte maturation: production of pyruvate in vitro. 7. Reprod. Fert. 17, 395.

KREBS, H. A. (1970) Rate control of the tricarboxylic acid cycle. Adv. Enzyme Reguln, 8, 335.

Murdoch, R. N. \& Wales, R. G. (1971) The synthesis of soluble-RNA in developing pre-implantation mouse embryos cultured in vitro in the presence of ${ }^{14} \mathrm{C}$-labelled pyruvate, glucose and carbon dioxide. F. Reprod. Fert. 24, 287.

O'Shea, T. \& Wales, R. G. (1968) Metabolism of $\left[1-{ }^{14} \mathrm{C}\right]$ sodium lactate and $\left[2-{ }^{14} \mathrm{C}\right]$ sodium lactate by ram spermatozoa. 7. Reprod. Fert. 15, 337.

Quinn, P. \& Wales, R. G. (1971) Fixation of carbon dioxide by preimplantation mouse embryos in vitro and the activities of enzymes involved in the process. Aust. F. biol. Sci. 24, 1277.

Quinn, P. \& Wales, R. G. (1973) The effect of culture in vitro on the levels of adenosine triphosphate in preimplantation mouse embryos 7. Reprod. Fert. 32, 231.

Reinius, S. (1969) Morphology of oviduct, gametes and zygotes as a basis of oviductal function in the mouse. Institute of Human Anatomy, University of Uppsala, Sweden.

Schmidt, K. \& KATz, J. (1969) Metabolism of pyruvate and L-lactate by rat adipose tissue. 7 . biol. Chem. 244, 2125.

SNEDECOR, G. W. (1957) Statistical methods applied to experiments in agriculture and biology, 5th edn. Iowa State College Press, Ames, Iowa.

Wales, R. G. \& Biggers, J. D. (1968) The permeability of two- and eight-cell mouse embryos to Lmalic acid. F. Reprod. Fert. 15, 103.

Wales, R. G. \& Whittingham, D. G. (1967) A comparison of the uptake and utilization of lactate and pyruvate by one- and two-cell mouse embryos. Biochim. biophys. Acta, 148, 703.

Wales, R. G. \& Whittingham, D. G. (1970) Metabolism of specifically labelled pyruvate by mouse embryos during culture from the two cell stage to the blastocyst. Aust. F. biol. Sci. 23, 877.

Wales, R. G. \& Whittingham, D. G. (1971) Decomposition of sodium pyruvate in culture media stored at $5^{\circ} \mathrm{C}$ and its effects on the development of the preimplantation mouse embryo. $\mathbf{J}$. Reprod. Fert. 24, 126 (Abstr.).

WALEs, R. G. \& Whittingham, D. G. (1973) The metabolism of specifically labelled lactate and pyruvate by two-cell mouse embryos. F. Reprod. Fert. 33, 207. 